\title{
UJI DAN SELEKSI ISOLAT KONSORSIUM MIKROB FILOSFER DAN RIZOSFER TERHADAP PERKECAMBAHAN BENIH PADI
}

\author{
ISOLATE TEST AND SELECTION OF PHYLLOSPHERE AND \\ RHIZOSPHERE MICROBIAL CONSORTIUM ON RICE SEEDS \\ GERMINATION
}

\author{
Aris Aksarah Pas ${ }^{1 *}$, Didy Sopandie ${ }^{2}$, Trikoesoemaningtyas², Dwi Andreas Santosa ${ }^{2}$ \\ ${ }^{1}$ Program Studi Agroteknologi, Fakultas Pertanian, Universitas Alkhairaat, Jl. Diponegoro, Fakultas \\ Pertanian Universitas Alkhairaat, Palu 94221, Indonesia \\ ${ }^{2}$ Program Studi Agronomi dan Hortikultura Fakultas Pertanian IPB, Bogor
}

\begin{abstract}
ABSTRAK
Aplikasi mikrob pada benih tanaman padi, mikrob dapat masuk ke dalam jaringan benih padi dan akan tumbuhan di dalam jaringan benih, mikrob tersebut dapat mengkolonisasi dan bertahan serta berkembang di dalam benih. Kolonisasi akan dilanjutkan pada saat tanaman tumbuh. Penelitian ini bertujuan melakukan seleksi terhadap konsorsium mikrob filosfer dan rizosfer yang dapat meningkatkan pertumbuhan tanaman. Selanjutnya memilih konsorsium mikrob filosfer dan rizosfer yang terbaik untuk diuji efektivitasnya dalam meningkatkan pertumbuhan tanaman padi. Metode pengujian dilakukan dengan cara merendam benih padi (seed treatment) pada masing-masing suspensi campuran selama 24 jam. Daya kecambah diamati setelah 2 hari inkubasi dan panjang akar, panjang tunas, bobot basah dan bobot kering semai diamati setelah 5 hari. Metode menggunakan Rancangan Acak Lengkap satu faktor perlakuan. Seleksi delapan isolat konsorsium terbaik dipilih berdasarkan ranking setelah masing-masing parameter diberi bobot dikali dengan skoring. Sampel yang diekplorasi dari berbagai ekosistem di Kabupaten Sigi mengandung konsorsium mikrob filosfer dan rizosfer. Isolat konsorsium mikrob filosfer dan rizosfer nyata memberikan pengaruh positif, netral dan negatif terhadap perkecambahan benih padi. Dapat diseleksi masing-masing delapan konsorsium mikrob filosfer dan rizosfer yang terbaik.
\end{abstract}

Katakunci: konsorsium mikrob, seleksi, filosfer, rizosfer, seed treatment

\section{ABSTRACT}

The application of microbes on the seeds of rice plants, microbes can enter into the rice seed tissues and growth in seed tissues, these microbes can colonize and survive and develop in the seeds. Colonization will continue when the plant grows. This study aims to select the phyllosphere and rhizosphere microbial consortium which can increase plant growth. Furthermore, choosing the best phyllosphere and rhizosphere microbial consortium to test its effectiveness in increasing rice growth. The test method was carried out by soaking the rice seeds (seed treatment) on each mixture suspension for 24 hours. Sprout power was observed after 2 days of incubation and root length, shoot length, wet weight and dry weight of seedlings were observed after 5 days. The method uses a Completely Randomized Design one treatment factor. The selection of the eight best consortium isolates was chosen based on the ranking after each parameter was given the weight multiplied by the scoring. The explored samples from various ecosystems in Sigi Regency contain the phyllosphere and rhizosphere microbial consortium. The isolates of the phyllosphere and rhizosphere microbial consortium have a positive, neutral and negative influence on rice seed germination. Can be selected for each of the eight best phyllosphere and rhizosphere microbial consortiums

Keywords: microbial consortium, selection, filosphere, rhizosphere, seed treatment 


\section{Pendahuluan}

Rangkaian kegiatan ekplorasi konsorsium mikrob setelah kultivasi adalah mengaplikasikan sedini mungkin pada tanaman untuk mengetahui dan menguji kemampuannya dalam meningkatkan pertumbuhan tanaman. Kemudian dapat diseleksi konsorsium mikrob yang berpengaruh positif terhadap tanaman.

Pertumbuhan awal tanaman pada fase perkecambahan akan menentukan pertumbuhan tanaman selanjutnya hingga dewasa. Proses pertumbuhan tanaman diawal dengan pembelahan sel, pembesaran sel dan terakhir diferensiasi sel. Pertumbuhan terjadi pada jaringan meristem yang terdiri dari sel-sel pada keadaan optimum dan pembelahan sel terjadi terus menerus. Jaringan meristem yang paling penting adalah ujung akar dan ujung dahan (Darmawan \& Baharsjah 2010).

Aplikasi mikrob pada benih tanaman padi, mikrob dapat masuk ke dalam jaringan benih padi dan akan tumbuhan di dalam jaringan benih, mikrob tersebut dapat mengkolonisasi dan bertahan serta berkembang di dalam benih. Kolonisasi akan dilanjutkan pada saat tanaman tumbuh (Fahey et al. 1991; Rao 2007). Lebih jauh Rao (2007) menyatakan, penyemprotan daun tanaman budidaya dengan suspensi bakteri telah menghasilkan adanya pertumbuhan yang dipercepat dan peningkatan hasil panen legum dan seralia tertentu yang ditanam dalam pot percobaan. Didukung oleh pendapat Sturz \& Nowak (2000), aplikasi mikrob dapat dilakukan melalui perendaman benih (seed treatment) dan penyemprotan pada tanaman muda. Pada saat benih dikeluarkan dari suspensi mikrob tetap berada dalam embrio.

Proses pertumbuhan tanaman memerlukan suatu mekanisme untuk pengaturan pertumbuhannya. Bahan pengatur tumbuh tersebut adalah hormon yang dibutuhkan dalam jumlah sedikit. Mikrob berperan sebagai agen peningkatan pertumbuhan tanaman (plant growth promoting agents), menghasilkan berbagai hormon tumbuh, vitamin dan berbagai asam organik yang berperan penting dalam merangsang pertumbuhan bulu-bulu akar. Mikrob juga memegang peran penting terhadap pertumbuhan tanaman, antara lain : proses penguraian bahan organik, melepaskan nutrisi ke

\footnotetext{
${ }^{*)}$ Penulis Korespondensi

E-mail: arisaksarahpas@gmail.com

Telp: +62-81341012887
}

dalam bentuk tersedia bagi tanaman dan mendegradasi residu toksik (Hindersah \& Tualar 2004).

Fitohormon yang disekresikan oleh mikrob berperan meregulasi pertumbuhan tanaman. Tanaman memenuhi kebutuhannya akan hormon melalui kemampuannya untuk mensintesis hormon atau mendapatkannya dari rizosfer dan filosfer sebagai akibat dari aktivitas mikroorganisme dalam mensintesis fitohormon. Hormon tanaman dikelompokkan ke dalam lima group, yaitu auksin, giberelin, sitokinin, etilen dan asam absisat (Hindersah \& Tualar 2004). Hasil penelitian Gofar (2003) menunjukkan bahwa konsorsium mikrob menghasilkan hormon auksin (IAA), giberelin $\left(\mathrm{GA}_{3}\right)$ dan Sitokinin. Fitohormon yang terkandung di dalam mikrob penyusun konsorsium merangsang pembentukan akar, sehingga serapan hara lebih efektif. Secara alami, akar berperan sebagai saluran untuk mensuplai unsur hara dan air dari tanah ke tanaman dan lokasi sintesis serta pertukaran sejumlah hormon dalam tanaman. Pertumbuhan akar yang normal menjamin perkembangan tajuk yang normal. Taiz \& Zeiger (1991) menyatakan bahwa, pertumbuhan dan perkembangan tanaman merupakan proses yang sangat kompleks. Kedua proses ini bergantung antara lain pada berbagai interaksi aktivitas kelima hormon tanaman.

Penelitian ini bertujuan melakukan seleksi terhadap konsorsium mikrob filosfer dan rizosfer yang dapat meningkatkan pertumbuhan tanaman. Selanjutnya memilih konsorsium mikrob filosfer dan rizosfer yang terbaik untuk diuji efektivitasnya dalam meningkatkan pertumbuhan tanaman padi.

\section{Metode Penelitian}

\section{Tempat dan Waktu}

Pelaksanaan penelitian dimulai Bulan Nopember 2012 hingga Pebruari 2013. Percobaan dilaksanakan di Laboratorium Bioteknologi Tanah, Departemen Ilmu Tanah dan Sumberdaya Lahan, Fakultas Pertanian, IPB.

\section{Bahan dan Alat}

Bahan yang digunakan terdiri dari : Bahan yang digunakan terdiri dari : 144 Isolat konsorsium mikrob filosfer, 48 isolat konsorsium mikrob rizosfer hasil eksplorasi sampel konsorsium dari Kabupaten Sigi, benih padi Varietas Ciherang, medium cair laurell, NB, kertas tissue, spiritus dan aquades. Alat yang 


\section{Jurnal Ogrotech 8 (2) 62-72}

digunakan : cawan petri, erlemeyer, pipet dan bunsen.

\section{Metode}

Metode menggunakan Rancangan Acak Lengkap (RAL) satu faktor perlakuan. Pengujian dilakukan dengan metode perendaman benih padi (seed teratment) pada masing-masing suspensi campuran isolat konsorsium mikrob filosfer dan rizosfer selama 24 jam, dengan diulang sebanyak 3 kali. Parameter yang diambil adalah daya kecambah diamati setelah dua hari inkubasi dan panjang akar, panjang tunas, bobot basah dan bobot kering semai diamati setelah 7 hari (Rustam 2012). Data yang diperoleh diolah degan analisis ragam dan apabila ada beda nyata dilajutkan dengan Uji jarak berganda Duncan pada taraf 5\%. Olah data menggunakan program computer SAS (Statistical Analysis System) for windows versi 9.1 (Matjik dan Sumertajaya 2006).

\section{Pelaksanaan}

Konsorsium mikrob filosfer ditumbuhkan dalam $50 \mathrm{ml}$ medium cair laurell $(0,5 \mathrm{~g} \mathrm{NaCl}, 1 \mathrm{~g}$ triptopan pepton, $0,5 \mathrm{~g}$ ekstrak ragi, dilarutkan dalam 1 liter aquades). Konsorsium mikrob rizosfer ditumbuhkan dalam $50 \mathrm{ml}$ larutan NB (8 $\mathrm{g} / 1+$ aquades). Kemudian diisi benih, sebagai pembanding benih direndam pada masing-masing larutan laurell dan larutan NB steril. Benih yang
e-ISSN : 2621-7236

p-ISSN : 1858-134X

telah direndam dipindahkan ke dalam cawan petri yang telah dilapisi dengan kertas saring lembab (steril) sebanyak 20 benih/cawan petri. Metode seleksi dilakukan berdasarkan metode skoring seperti yang dilakukan Vaish et al. (2011). Keseluruhan data pengamatan diberi bobot dan dari setiap perlakuan diberikan skor berdasarkan nilai terendah hingga tertinggi menurut jumlah perlakuan. Setelah masingmasing parameter diberi bobot dikali dengan skoring, dipilih delapan ranking tertinggi.

\section{Hasil}

Filosfer

Hasil sidik ragam menunjukkan bahwa perlakuan perendaman benih padi pada isolat konsorsium mikrob filosfer daun muda, daun sedang dan daun tua berpengaruh nyata terhadap perkecambahan benih padi. Hasil uji lanjut DMRT pada taraf a $5 \quad \%$ masing-masing parameter panjang akar, panjang daun, bobot basah kecambah dan bobot kering kecambah berbeda nyata dengan kontrol.

Rata-rata panjang akar, panjang daun, bobot segar dan bobot kering kecambah benih padi terhadap perlakuan perendaman isolat konsorsium mikrob filosfer daun muda (Fm), daun sedang $(\mathrm{Fs})$ dan daun tua $(\mathrm{Ft})$ serta nilai skor disajikan pada Tabel 1,2 dan 3 .

Tabel 1. Rata-rata panjang akar (cm), panjang daun $(\mathrm{cm})$, bobot segar $(\mathrm{g})$ dan bobot kering $(\mathrm{g})$ kecambah benih padi terhadap perlakuan perendaman konsorsium mikrob filosfer daun muda (Fm)

\begin{tabular}{|c|c|c|c|c|c|c|c|c|c|}
\hline No & Kode Isolat & $\begin{array}{l}\text { Panjang } \\
\text { akar }\end{array}$ & Skor & $\begin{array}{l}\text { Panjang } \\
\text { daun }\end{array}$ & Skor & $\begin{array}{l}\text { Bobot } \\
\text { segar }\end{array}$ & Skor & $\begin{array}{l}\text { Bobot } \\
\text { kering }\end{array}$ & Skor \\
\hline 1 & Fm0 = Kontrol & 6.5700 & 19 & 3.9233 & 2 & 0.0658 & 21 & 0.0224 & 2 \\
\hline 2 & Fm1 = Lantana camara $\mathrm{L}$ & 7.0067 & 32 & 4.8333 & 41 & 0.0812 & 44 & 0.0248 & 43 \\
\hline 3 & Fm2 = Ageratum conyzoides $\mathrm{L}$. & 7.1833 & 36 & 4.5233 & 28 & 0.0539 & 9 & 0.0254 & 48 \\
\hline 4 & Fm3 = Jussiaea suffruticsa L. & 6.4833 & 16 & 3.7133 & 1 & 0.0587 & 13 & 0.0234 & 17 \\
\hline 5 & Fm4 = Bidens pilosa $\mathrm{L}$ & 8.0300 & 48 & 4.4867 & 24 & 0.0689 & 24 & 0.0231 & 7 \\
\hline 6 & Fm5 = E. prunifolia Jacq & 6.0267 & 7 & 4.0867 & 5 & 0.0595 & 15 & 0.0232 & 11 \\
\hline 7 & Fm6 = O. sompositus Beauv & 5.4733 & 2 & 4.3167 & 11 & 0.0550 & 11 & 0.0224 & 2 \\
\hline 8 & Fm7 = Ipomoa quamoclit L & 6.9500 & 30 & 4.8800 & 44 & 0.0742 & 35 & 0.0242 & 38 \\
\hline 9 & Fm8 = D. agrotistachya Steud & 6.4833 & 16 & 4.3967 & 21 & 0.0439 & 5 & 0.0246 & 42 \\
\hline 10 & Fm9 = Hyptis capitata Jacq. & 6.5367 & 18 & 4.4200 & 22 & 0.0793 & 40 & 0.0239 & 31 \\
\hline 11 & Fm10 = S. pictus Hassk. & 6.8433 & 24 & 4.3500 & 14 & 0.0715 & 29 & 0.0237 & 23 \\
\hline 12 & Fm11 = L. leucocephala Lam. & 6.1833 & 12 & 4.3733 & 17 & 0.0741 & 34 & 0.0233 & 15 \\
\hline 13 & Fm12 = Ruellia tuberosa L. & 6.2400 & 13 & 4.5733 & 32 & 0.0594 & 14 & 0.0231 & 7 \\
\hline 14 & Fm13 = B. mutica Forsk & 6.4633 & 15 & 4.8367 & 42 & 0.0583 & 12 & 0.0238 & 28 \\
\hline 15 & Fm14 = S. sarasinorum & 7.0167 & 33 & 4.4867 & 24 & 0.0759 & 36 & 0.0238 & 28 \\
\hline 16 & Fm15 = Physalis angulata $\mathrm{L}$. & 6.8667 & 25 & 4.4700 & 23 & 0.0829 & 46 & 0.0245 & 39 \\
\hline 17 & Fm16 = E. crus-galli L. & 6.8733 & 26 & 4.6167 & 34 & 0.0705 & 27 & 0.0228 & 6 \\
\hline 18 & Fm17 = Piper aduncum L. & 6.9733 & 31 & 4.7033 & 35 & 0.0838 & 47 & 0.0252 & 47 \\
\hline 19 & Fm18 = Curculigo latifolia $\mathrm{L}$. & 7.3400 & 38 & 4.8967 & 45 & 0.0612 & 17 & 0.0237 & 23 \\
\hline 20 & Fm19 = V. rubescens Blume. & 7.5100 & 39 & 5.1267 & 49 & 0.0790 & 38 & 0.0232 & 11 \\
\hline 21 & Fm20 = C. vulgare Leeench. & 5.7000 & 5 & 4.0233 & 4 & 0.0651 & 20 & 0.0234 & 17 \\
\hline
\end{tabular}




\begin{tabular}{|c|c|c|c|c|c|c|c|c|c|}
\hline \multicolumn{10}{|c|}{ Lanjutan } \\
\hline 22 & Fm21 = L. capitellata Wedd. & 5.1233 & 1 & 4.5167 & 27 & 0.0278 & 1 & 0.0237 & 23 \\
\hline 23 & $\mathrm{Fm} 22=$ G. linearis Burm.f. & 6.6167 & 20 & 4.3467 & 13 & 0.0698 & 26 & 0.0231 & 7 \\
\hline 24 & Fm23 = Mimosa invisa Mart. & 7.0333 & 34 & 4.5567 & 31 & 0.0458 & 7 & 0.0226 & 4 \\
\hline 25 & Fm24 = Euphorbia hirta L. & 6.1733 & 11 & 4.1800 & 7 & 0.0709 & 28 & 0.0237 & 23 \\
\hline 26 & Fm25 = P. celebicum Miq. & 7.6733 & 43 & 4.8667 & 43 & 0.0791 & 39 & 0.0239 & 31 \\
\hline 27 & Fm26 = N. ventricosa Ridsd. & 5.6967 & 4 & 4.0033 & 3 & 0.0634 & 19 & 0.0240 & 36 \\
\hline 28 & Fm27 = C. mucunoides Desv. & 7.9500 & 47 & 4.7600 & 40 & 0.0799 & 41 & 0.0234 & 17 \\
\hline 29 & Fm28 = M.cochinchinensis Lour & 6.9167 & 29 & 4.4933 & 26 & 0.0631 & 18 & 0.0236 & 22 \\
\hline 30 & Fm29 = Senna siamea Lam. & 6.0267 & 7 & 4.3900 & 20 & 0.0546 & 10 & 0.0249 & 44 \\
\hline 31 & Fm30 = M. multiglandulosus & 6.1233 & 10 & 4.5367 & 29 & 0.0802 & 42 & 0.0231 & 7 \\
\hline 32 & Fm31 = Sida rhombifolia L. & 7.1800 & 35 & 4.2100 & 8 & 0.0732 & 32 & 0.0233 & 15 \\
\hline 33 & Fm32 = J. gossypifolia L. & 6.8800 & 27 & 4.3733 & 16 & 0.0404 & 2 & 0.0245 & 39 \\
\hline 34 & Fm33 = C. gigantea R.Br. & 6.6567 & 22 & 4.5800 & 33 & 0.0424 & 4 & 0.0210 & 1 \\
\hline 35 & Fm34 = B. microphylla Kurz & 7.5133 & 40 & 4.7067 & 34 & 0.0718 & 30 & 0.0239 & 31 \\
\hline 36 & Fm35 = Eleusina indica Gaerth & 7.5433 & 41 & 4.3300 & 12 & 0.1004 & 49 & 0.0239 & 31 \\
\hline 37 & Fm36 = C. anagyroides H.B.K. & 5.7867 & 6 & 4.1000 & 6 & 0.0771 & 37 & 0.0245 & 39 \\
\hline 38 & Fm37 = S. brachycladum L. & 6.9000 & 28 & 4.3700 & 15 & 0.0485 & 8 & 0.0232 & 11 \\
\hline 39 & Fm38 = S. jamaicensis L. & 7.7033 & 44 & 5.0567 & 48 & 0.0816 & 45 & 0.0251 & 45 \\
\hline 40 & Fm39 = I. rugosum Salisb. & 8.3200 & 49 & 4.7033 & 35 & 0.0675 & 23 & 0.0251 & 45 \\
\hline 41 & Fm40 $=$ C. tenuispica Steud & 6.2767 & 14 & 4.3833 & 19 & 0.0441 & 6 & 0.0232 & 11 \\
\hline 42 & Fm41 = Cuphea balsam L. & 7.8433 & 45 & 4.3800 & 18 & 0.0418 & 3 & 0.0234 & 17 \\
\hline 43 & Fm42 = Scoparia dulcis L. & 6.1033 & 9 & 4.2333 & 9 & 0.0606 & 16 & 0.0238 & 28 \\
\hline 44 & Fm43 = E. odoratum L. & 5.5833 & 3 & 4.3133 & 10 & 0.0680 & 24 & 0.0239 & 31 \\
\hline 45 & Fm44 = C. prostrate Blume. & 7.6367 & 42 & 4.7467 & 39 & 0.0668 & 22 & 0.0240 & 36 \\
\hline 46 & Fm45 = E. subumbrans Merr. & 6.6400 & 21 & 4.5467 & 30 & 0.0807 & 43 & 0.0234 & 17 \\
\hline 47 & Fm46 = C.crepidioides $\mathrm{L}$. & 7.2500 & 37 & 4.7067 & 37 & 0.0728 & 31 & 0.0226 & 4 \\
\hline 48 & Fm47 = Ficus minahassae L. & 6.7067 & 23 & 4.9133 & 46 & 0.0734 & 33 & 0.0237 & 23 \\
\hline 49 & Fm48 = E. ovalis Miq. Dandy. & 7.8967 & 46 & 4.9767 & 47 & 0.0929 & 8 & 0.0254 & 8 \\
\hline
\end{tabular}

Keterangan : $\mathrm{n}=$ berpengaruh nyata

Tabel 2. Rata-rata panjang akar $(\mathrm{cm})$, panjang daun $(\mathrm{cm})$, bobot segar $(\mathrm{g})$ dan bobot kering $(\mathrm{g})$ kecambah benih padi terhadap perlakuan perendaman konsorsium mikrob filosfer daun sedang (Fs)

\begin{tabular}{|c|c|c|c|c|c|c|c|c|c|}
\hline No. & Kode Isolat & $\begin{array}{l}\text { Panjang } \\
\text { akar }\end{array}$ & Skor & $\begin{array}{l}\text { Panjang } \\
\text { daun }\end{array}$ & Skor & $\begin{array}{l}\text { Bobot } \\
\text { segar }\end{array}$ & Skor & $\begin{array}{l}\text { Bobot } \\
\text { kering }\end{array}$ & Skor \\
\hline 1 & Fs0 = Kontrol & 5.9733 & 11 & 3.7933 & 18 & 0.0738 & 13 & 0.0215 & 1 \\
\hline 2 & Fs 1 = Lantana camara $\mathrm{L}$. & 6.2100 & 14 & 3.5500 & 8 & 0.0716 & 11 & 0.0224 & 15 \\
\hline 3 & Fs $2=$ Ageratum conyzoides $\mathrm{L}$. & 7.0433 & 44 & 4.5167 & 49 & 0.0929 & 35 & 0.0234 & 44 \\
\hline 4 & Fs3 = Jussiaea suffruticsa $\mathrm{L}$. & 4.7100 & 1 & 3.0167 & 1 & 0.0599 & 6 & 0.0217 & 4 \\
\hline 5 & Fs4 = Bidens pilosa $\mathrm{L}$ & 6.1400 & 13 & 3.9900 & 28 & 0.1006 & 37 & 0.0223 & 11 \\
\hline 6 & Fs5 = E. prunifolia Jacq & 5.0267 & 4 & 3.4133 & 4 & 0.0534 & 2 & 0.0224 & 15 \\
\hline 7 & Fs6 $=$ O. sompositus Beauv & 5.6367 & 7 & 3.6300 & 12 & 0.0643 & 9 & 0.0227 & 24 \\
\hline 8 & Fs7 = Ipomoa quamoclit L & 5.7767 & 7 & 3.7900 & 17 & 0.0593 & 5 & 0.0223 & 11 \\
\hline 9 & Fs8 = D. agrotistachya Steud. & 6.5033 & 27 & 4.0633 & 34 & 0.1022 & 39 & 0.0224 & 15 \\
\hline 10 & Fs9 = Hyptis capitata Jacq. & 6.8333 & 41 & 4.1767 & 39 & 0.0980 & 36 & 0.0232 & 39 \\
\hline 11 & Fs10 = S. pictus Hassk. & 5.9967 & 12 & 4.3367 & 46 & 0.0646 & 10 & 0.0245 & 49 \\
\hline 12 & Fs11 = L. leucocephala Lam. & 5.4367 & 6 & 3.5633 & 9 & 0.0756 & 14 & 0.0228 & 26 \\
\hline 13 & Fs12 = Ruellia tuberosa $\mathrm{L}$ & 6.3367 & 18 & 3.8467 & 20 & 0.0917 & 32 & 0.0215 & 1 \\
\hline 14 & Fs13 = B. mutica Forsk. & 6.5800 & 31 & 4.0900 & 35 & 0.0828 & 25 & 0.0230 & 35 \\
\hline 15 & Fs14 = S. sarasinorum & 6.4200 & 24 & 3.5167 & 7 & 0.0784 & 18 & 0.0229 & 31 \\
\hline 16 & Fs15 = Physalis angulata $\mathrm{L}$. & 6.5400 & 30 & 3.3567 & 3 & 0.0814 & 21 & 0.0226 & 21 \\
\hline 17 & Fs $16=$ E. crus-galli $\mathrm{L}$ & 4.8333 & 3 & 3.6033 & 11 & 0.0856 & 27 & 0.0220 & 7 \\
\hline 18 & Fs17 = Piper aduncum L. & 7.2167 & 46 & 4.2000 & 41 & 0.0894 & 30 & 0.0233 & 43 \\
\hline 19 & Fs18 = Curculigo latifolia $\mathrm{L}$. & 6.3567 & 20 & 3.6433 & 13 & 0.1061 & 42 & 0.0221 & 9 \\
\hline 20 & Fs19=V.rubescens Blume. & 6.2467 & 16 & 3.5767 & 10 & 0.0925 & 34 & 0.0237 & 46 \\
\hline
\end{tabular}


Lanjutan

\begin{tabular}{|c|c|c|c|c|c|c|c|c|c|}
\hline 21 & Fs20 $=C$. vulgare Leeench. & 7.4267 & 48 & 4.0567 & 33 & 0.0822 & 24 & 0.0232 & 39 \\
\hline 22 & Fs $21=L$. capitellata Wedd. & 6.6267 & 33 & 4.2533 & 43 & 0.1096 & 44 & 0.0244 & 48 \\
\hline 23 & Fs22 = G. linearis Burm.f. & 6.8033 & 39 & 3.9833 & 26 & 0.0862 & 28 & 0.0228 & 26 \\
\hline 24 & Fs23 = Mimosa invisa Mart. & 5.7867 & 9 & 3.4233 & 5 & 0.0551 & 4 & 0.0215 & 1 \\
\hline 25 & Fs24 = Euphorbia hirta L. & 6.2533 & 17 & 4.0967 & 36 & 0.1050 & 41 & 0.0226 & 21 \\
\hline 26 & Fs $25=P$. celebicum Miq. & 7.0367 & 43 & 4.2900 & 45 & 0.1273 & 48 & 0.0232 & 39 \\
\hline 27 & Fs $26=N$. ventricosa Ridsd & 6.8233 & 40 & 4.1100 & 37 & 0.0836 & 26 & 0.0237 & 46 \\
\hline 28 & Fs27 = C. mucunoides Desv. & 6.2300 & 15 & 4.5100 & 48 & 0.0613 & 8 & 0.0224 & 15 \\
\hline 29 & Fs28 = M.cochinchinensis Lour & 8.0167 & 49 & 4.3533 & 47 & 0.1576 & 49 & 0.0230 & 35 \\
\hline 30 & Fs29 = Senna siamea Lam. & 6.5300 & 28 & 4.0367 & 32 & 0.0822 & 23 & 0.0229 & 31 \\
\hline 31 & Fs30 = M. multiglandulosus & 6.6533 & 28 & 3.8800 & 22 & 0.0807 & 20 & 0.0232 & 39 \\
\hline 32 & Fs31 = Sida rhombifolia L. & 6.4633 & 26 & 3.9867 & 27 & 0.0887 & 29 & 0.0231 & 37 \\
\hline 33 & Fs32 = J. gossypifolia L. & 6.5967 & 32 & 4.2667 & 44 & 0.0897 & 31 & 0.0228 & 36 \\
\hline 34 & $\mathrm{Fs} 33=$ C. gigantea $\mathrm{R} . \mathrm{Br}$. & 6.7267 & 37 & 4.1900 & 40 & 0.1152 & 46 & 0.0234 & 44 \\
\hline 35 & Fs34 = B. microphylla Kurz & 4.7200 & 2 & 3.2867 & 2 & 0.0486 & 1 & 0.0217 & 4 \\
\hline 36 & Fs35 = Eleusina indica Gaerth. & 6.3400 & 19 & 3.9033 & 23 & 0.1238 & 47 & 0.0224 & 15 \\
\hline 37 & Fs $36=C$. anagyroides H.B.K. & 5.3500 & 5 & 3.4900 & 6 & 0.0544 & 3 & 0.0225 & 20 \\
\hline 38 & Fs $37=$ S. brachycladum L. & 6.6267 & 33 & 4.1333 & 38 & 0.0919 & 33 & 0.0229 & 31 \\
\hline 39 & Fs38 = S. jamaicensis L. & 6.5333 & 29 & 3.9633 & 25 & 0.0815 & 22 & 0.0229 & 31 \\
\hline 40 & Fs39 = I. rugosum Salisb. & 6.4267 & 25 & 3.8133 & 19 & 0.0770 & 17 & 0.0226 & 21 \\
\hline 41 & Fs40 $=$ C. tenuispica Steud & 6.3600 & 21 & 3.7167 & 15 & 0.0758 & 15 & 0.0221 & 9 \\
\hline 42 & Fs41 = Cuphea balsam L. & 7.2533 & 41 & 3.8600 & 21 & 0.0724 & 12 & 0.0218 & 6 \\
\hline 43 & Fs42 = Scoparia dulcis L. & 5.8600 & 10 & 3.7367 & 16 & 0.0800 & 19 & 0.0220 & 7 \\
\hline 44 & Fs43 = E. odoratum L. & 6.6900 & 36 & 4.0067 & 31 & 0.0759 & 16 & 0.0223 & 11 \\
\hline 45 & Fs $44=C$. prostrate Blume. & 6.4067 & 23 & 3.7133 & 14 & 0.0600 & 7 & 0.0223 & 11 \\
\hline 46 & Fs45 = E. subumbrans Merr. & 6.7900 & 38 & 4.2433 & 45 & 0.1077 & 43 & 0.0228 & 26 \\
\hline 47 & Fs46 = C.crepidioides L. & 7.0600 & 45 & 3.9967 & 30 & 0.1028 & 40 & 0.0227 & 24 \\
\hline 48 & Fs47 = Ficus minahassae L. & 6.8900 & 42 & 3.9933 & 29 & 0.1122 & 45 & 0.0228 & 26 \\
\hline \multirow[t]{2}{*}{49} & Fs $48=$ E. ovalis Miq. Dandy. & 6.3733 & 22 & 3.9133 & 24 & 0.1007 & 38 & 0.0231 & 7 \\
\hline & & $n$ & & $n$ & & $n$ & & $n$ & \\
\hline
\end{tabular}

Keterangan $: \mathrm{n}=$ berpengaruh nyata

Tabel 3. Rata-rata panjang akar $(\mathrm{cm})$, panjang daun $(\mathrm{cm})$, bobot segar $(\mathrm{g})$ dan bobot kering $(\mathrm{g})$ kecambah benih padi terhadap perlakuan perendaman konsorsium mikrob filosfer daun tua $(\mathrm{Ft})$

\begin{tabular}{|c|c|c|c|c|c|c|c|c|c|}
\hline No. & Kode Isolat & $\begin{array}{l}\text { Panjang } \\
\text { akar }\end{array}$ & Skor & $\begin{array}{l}\text { Panjang } \\
\text { daun }\end{array}$ & $\begin{array}{l}\text { Sko } \\
\text { r }\end{array}$ & $\begin{array}{l}\text { Bobot } \\
\text { segar }\end{array}$ & Skor & $\begin{array}{l}\text { Bobot } \\
\text { kering }\end{array}$ & Skor \\
\hline 1 & Ft0 = Kontrol & 4.8800 & 5 & 3.7500 & 6 & 0.0694 & 16 & 0.0223 & 9 \\
\hline 2 & Ft1 = Lantana camara $\mathrm{L}$ & 6.1667 & 18 & 5.2033 & 42 & 0.0810 & 39 & 0.0236 & 35 \\
\hline 3 & $\mathrm{Ft} 2=$ Ageratum conyzoides $\mathrm{L}$. & 8.6767 & 49 & 5.6500 & 49 & 0.0955 & 47 & 0.0240 & 41 \\
\hline 4 & Ft3 = Jussiaea suffruticsa $\mathrm{L}$. & 7.0733 & 30 & 4.5467 & 23 & 0.0729 & 22 & 0.0238 & 38 \\
\hline 5 & $\mathrm{Ft} 4=$ Bidens pilos $a \mathrm{~L}$ & 6.9700 & 27 & 4.4467 & 20 & 0.0775 & 33 & 0.0230 & 19 \\
\hline 6 & $\mathrm{Ft} 5=$ E. prunifolia $\mathrm{Jacq}$ & 6.8033 & 22 & 4.4167 & 18 & 0.0737 & 24 & 0.0226 & 15 \\
\hline 7 & Ft6 $=$ O. sompositus Beauv & 4.9700 & 6 & 3.7333 & 5 & 0.0663 & 5 & 0.0222 & 7 \\
\hline 8 & Ft7 = Ipomoa quamoclit $\mathrm{L}$ & 6.0867 & 17 & 4.7167 & 27 & 0.0662 & 4 & 0.0225 & 13 \\
\hline 9 & Ft8 $=$ D. agrotistachya Steud. & 5.9767 & 15 & 4.1767 & 14 & 0.0740 & 25 & 0.0221 & 6 \\
\hline 10 & Ft9 = Hyptis capitata Jacq. & 7.8933 & 43 & 5.3633 & 45 & 0.0846 & 42 & 0.0232 & 25 \\
\hline 11 & $\mathrm{Ft} 10=S$. pictus Hassk. & 7.7633 & 39 & 5.1567 & 41 & 0.0762 & 30 & 0.0234 & 32 \\
\hline 12 & Ft11 = L. leucocephala Lam. & 5.6667 & 11 & 3.3233 & 3 & 0.0643 & 1 & 0.0203 & 1 \\
\hline 13 & Ft12 = Ruellia tuberosa L. & 7.0367 & 29 & 4.9633 & 36 & 0.0778 & 34 & 0.0233 & 30 \\
\hline 14 & Ft13 = B. mutica Forsk. & 4.0067 & 3 & 4.0100 & 10 & 0.0758 & 28 & 0.0232 & 25 \\
\hline 15 & $\mathrm{Ft} 14=S$. sarasinorum & 5.7000 & 12 & 4.8567 & 32 & 0.0746 & 26 & 0.0231 & 21 \\
\hline 16 & Ft15 = Physalis angulata $\mathrm{L}$. & 7.9833 & 45 & 5.2467 & 44 & 0.0885 & 45 & 0.0250 & 47 \\
\hline 17 & Ft16 = E. crus-galli L. & 5.7367 & 13 & 4.5200 & 22 & 0.0769 & 31 & 0.0226 & 15 \\
\hline 18 & Ft17 = Piper aduncum L. & 8.5467 & 45 & 5.5667 & 47 & 0.0721 & 21 & 0.0232 & 25 \\
\hline 19 & Ft18 = Curculigo latifolia $\mathrm{L}$. & 5.4667 & 9 & 4.7333 & 28 & 0.0711 & 18 & 0.0230 & 19 \\
\hline 20 & Ft19 = V. rubescens Blume. & 6.8300 & 23 & 4.9800 & 37 & 0.0732 & 23 & 0.0238 & 38 \\
\hline 21 & $\mathrm{Ft} 20=C$. vulgare Leeench. & 3.4733 & 2 & 3.0300 & 2 & 0.0653 & 3 & 0.0218 & 5 \\
\hline
\end{tabular}


Lanjutan

\begin{tabular}{|c|c|c|c|c|c|c|c|c|c|}
\hline 22 & $\mathrm{Ft} 21=$ L. capitellata Wedd. & 6.5167 & 21 & 4.1267 & 12 & 0.0683 & 10 & 0.0222 & 7 \\
\hline 23 & Ft22 = G. linearis Burm.f. & 5.4033 & 7 & 5.2367 & 43 & 0.0681 & 8 & 0.0238 & 38 \\
\hline 24 & Ft23 = Mimosa invisa Mart. & 7.8367 & 42 & 4.9033 & 34 & 0.0690 & 14 & 0.0224 & 11 \\
\hline 25 & Ft24 = Euphorbia hirta L. & 8.2900 & 47 & 5.0867 & 38 & 0.0846 & 43 & 0.0233 & 30 \\
\hline 26 & Ft25 = P. celebicum Miq. & 7.6667 & 38 & 4.8000 & 30 & 0.0761 & 29 & 0.0254 & 48 \\
\hline 27 & Ft26 $=N$. ventricos $a$ Ridsd & 7.1333 & 31 & 5.1100 & 39 & 0.0865 & 44 & 0.0241 & 42 \\
\hline 28 & Ft27 = C. mucunoides Desv. & 7.3733 & 35 & 3.9933 & 8 & 0.0827 & 41 & 0.0236 & 35 \\
\hline 29 & Ft28 = M.cochinchinensis Lour & 7.0333 & 28 & 4.5567 & 24 & 0.0712 & 19 & 0.0232 & 25 \\
\hline 30 & Ft29 = Senna siamea Lam. & 7.9367 & 44 & 4.4133 & 17 & 0.0933 & 46 & 0.0254 & 48 \\
\hline 31 & Ft30 = M. multiglandulosus & 7.8133 & 40 & 4.3233 & 16 & 0.0969 & 48 & 0.0241 & 42 \\
\hline 32 & Ft31 = Sida rhombifolia L. & 7.4000 & 36 & 4.6767 & 26 & 0.0809 & 38 & 0.0231 & 21 \\
\hline 33 & Ft32 = J. gossypifolia L. & 5.5600 & 10 & 3.8967 & 7 & 0.0665 & 6 & 0.0212 & 3 \\
\hline 34 & $\mathrm{Ft} 33=$ C. gigantea $\mathrm{R} . \mathrm{Br}$. & 7.8333 & 41 & 5.4267 & 46 & 0.0821 & 40 & 0.0243 & 46 \\
\hline 35 & Ft34 = B. microphylla Kurz & 1.9867 & 1 & 2.6367 & 1 & 0.0685 & 11 & 0.0223 & 9 \\
\hline 36 & Ft35 = Eleusina indica Gaerth. & 5.0933 & 7 & 4.8867 & 33 & 0.0681 & 8 & 0.0237 & 37 \\
\hline 37 & Ft36 = C. anagyroides H.B.K. & 7.3400 & 34 & 5.5833 & 48 & 0.0775 & 32 & 0.0229 & 17 \\
\hline 38 & Ft37 = S. brachycladum L. & 7.1600 & 33 & 4.8300 & 31 & 0.0788 & 35 & 0.0225 & 13 \\
\hline 39 & $\mathrm{Ft} 38=S$. jamaicensis $\mathrm{L}$ & 7.1467 & 32 & 4.2533 & 15 & 0.0792 & 36 & 0.0229 & 17 \\
\hline 40 & Ft39 = I. rugosum Salisb. & 7.4467 & 37 & 4.4733 & 21 & 0.0746 & 27 & 0.0231 & 21 \\
\hline 41 & $\mathrm{Ft} 40=C$. tenuispica Steud & 6.4133 & 20 & 4.0000 & 9 & 0.0692 & 15 & 0.0216 & 4 \\
\hline 42 & Ft41 = Cuphea balsam L. & 4.8633 & 4 & 3.6933 & 4 & 0.0680 & 7 & 0.0210 & 2 \\
\hline 43 & $\mathrm{Ft} 42=$ Scoparia dulcis $\mathrm{L}$. & 6.0267 & 16 & 4.1167 & 11 & 0.0705 & 17 & 0.0232 & 25 \\
\hline 44 & $\mathrm{Ft} 43=$ E. odoratum L. & 6.9167 & 26 & 4.6167 & 25 & 0.0801 & 37 & 0.0236 & 34 \\
\hline 45 & Ft44 = C. prostrate Blume. & 6.8467 & 24 & 4.1467 & 13 & 0.0688 & 12 & 0.0234 & 32 \\
\hline 46 & Ft45 = E. subumbrans Merr. & 6.3367 & 19 & 4.4433 & 19 & 0.0652 & 2 & 0.0224 & 11 \\
\hline 47 & Ft46 = C.crepidioides L. & 5.7800 & 14 & 4.7633 & 29 & 0.0690 & 13 & 0.0231 & 21 \\
\hline 48 & Ft47 = Ficus minahassae L. & 8.1467 & 46 & 5.1167 & 40 & 0.0714 & 20 & 0.0241 & 42 \\
\hline 49 & Ft48 = E. ovalis Miq. Dandy. & 6.8967 & 25 & 4.9100 & 35 & 0.0992 & 49 & 0.0241 & 2 \\
\hline
\end{tabular}

Keterangan : $\mathrm{n}=$ berpengaruh nyata

Rekapitulasi ranking isolat konsorsium bobot disajikan pada Tabel 4. mikrob filosfer terpilih berdasarkan skoring $\mathrm{x}$

Tabel 4. Rekapitulasi ranking isolat konsorsium mikrob filosfer terpilih berdasarkan skoring $\mathrm{x}$ bobot

\begin{tabular}{|c|c|c|c|c|c|c|c|c|c|c|c|}
\hline \multirow[t]{2}{*}{ No. } & \multirow{2}{*}{$\begin{array}{l}\text { Kode } \\
\text { Isolat }\end{array}$} & \multicolumn{2}{|c|}{$\begin{array}{l}\text { Panjang akar } \\
\text { bobot } 20(\mathrm{~b})\end{array}$} & \multicolumn{2}{|c|}{$\begin{array}{c}\text { Panjang daun } \\
\text { bobot } 20(\mathrm{~b})\end{array}$} & \multicolumn{2}{|c|}{$\begin{array}{l}\text { Bobot segar } \\
\text { (bobot 15)(b) }\end{array}$} & \multicolumn{2}{|c|}{$\begin{array}{l}\text { Boot kering } \\
\text { (bobot 30)(b) }\end{array}$} & \multirow[t]{2}{*}{ Total } & \multirow[t]{2}{*}{ Ranking } \\
\hline & & $\begin{array}{l}\text { Skor } \\
\text { (s) }\end{array}$ & $\begin{array}{l}\text { Hasil } \\
(\mathrm{s} x \mathrm{x})\end{array}$ & $\begin{array}{l}\text { Skor } \\
\text { (s) }\end{array}$ & $\begin{array}{l}\text { Hasil } \\
(\mathrm{s} \times \mathrm{x} \text { b) }\end{array}$ & $\begin{array}{l}\text { Skor } \\
\text { (s) }\end{array}$ & $\begin{array}{l}\text { Hasil } \\
\text { (s x b) }\end{array}$ & $\begin{array}{l}\text { Skor } \\
\text { (s) }\end{array}$ & $\begin{array}{c}\text { Hasil } \\
\text { (s x b) }\end{array}$ & & \\
\hline 1 & Fm48 & 46 & 920.00 & 47 & 940.00 & 48 & 720.00 & 48 & 1440.00 & 4020.00 & 1 \\
\hline 2 & Fm38 & 44 & 880.00 & 48 & 960.00 & 45 & 675.00 & 45 & 1350.00 & 3865.00 & 2 \\
\hline 3 & Fm17 & 31 & 620.00 & 35 & 700.00 & 47 & 705.00 & 47 & 1410.00 & 3435.00 & 3 \\
\hline 4 & Fm1 & 32 & 640.00 & 41 & 820.00 & 44 & 660.00 & 43 & 1290.00 & 3410.00 & 4 \\
\hline 5 & Fm39 & 49 & 980.00 & 35 & 700.00 & 23 & 345.00 & 45 & 1350.00 & 3375.00 & 5 \\
\hline 6 & Fm25 & 43 & 860.00 & 43 & 860.00 & 39 & 585.00 & 31 & 930.00 & 3235.00 & 6 \\
\hline 7 & Fm7 & 30 & 600.00 & 44 & 880.00 & 35 & 525.00 & 38 & 1140.00 & 3145.00 & 7 \\
\hline 8 & Fm44 & 42 & 840.00 & 39 & 780.00 & 22 & 330.00 & 36 & 1080.00 & 3030.00 & 8 \\
\hline 9 & Fm0 & 19 & 380.00 & 2 & 40.00 & 21 & 315.00 & 2 & 60.00 & 795.00 & kontrol \\
\hline 10 & Fs 28 & 49 & 980.00 & 47 & 940.00 & 49 & 735.00 & 35 & 1080.00 & 3705.00 & 1 \\
\hline 11 & Fs2 & 44 & 880.00 & 49 & 980.00 & 35 & 525.00 & 44 & 1320.00 & 3705.00 & 2 \\
\hline 12 & Fs25 & 43 & 860.00 & 45 & 900.00 & 48 & 720.00 & 39 & 1170.00 & 3650.00 & 3 \\
\hline 13 & Fs21 & 33 & 660.00 & 43 & 860.00 & 44 & 660.00 & 48 & 1440.00 & 3620.00 & 4 \\
\hline 14 & Fs33 & 37 & 740.00 & 40 & 800.00 & 46 & 690.00 & 44 & 1320.00 & 3550.00 & 5 \\
\hline 15 & Fs17 & 46 & 920.00 & 41 & 820.00 & 30 & 450.00 & 43 & 1290.00 & 3480.00 & 6 \\
\hline 16 & Fs9 & 41 & 820.00 & 39 & 780.00 & 36 & 540.00 & 39 & 1170.00 & 3310.00 & 7 \\
\hline 17 & Fs20 & 48 & 960.00 & 33 & 660.00 & 24 & 360.00 & 39 & 1170.00 & 3150.00 & 8 \\
\hline 18 & $\mathrm{FsO}$ & 11 & 220.00 & 18 & 360.00 & 13 & 195.00 & 1 & 30.00 & 805.00 & kontrol \\
\hline 19 & $\mathrm{Ft} 2$ & 49 & 980.00 & 49 & 980.00 & 47 & 705.00 & 41 & 1230.00 & 3895.00 & 1 \\
\hline 20 & Ft15 & 45 & 900.00 & 44 & 880.00 & 45 & 660.00 & 47 & 1410.00 & 3850.00 & 2 \\
\hline 21 & Ft33 & 41 & 820.00 & 46 & 920.00 & 40 & 600.00 & 46 & 1380.00 & 3720.00 & 3 \\
\hline
\end{tabular}




\begin{tabular}{clcccccccccc}
\hline 22 & Ft29 & 44 & 880.00 & 17 & 340.00 & 46 & 690.00 & 48 & 1440.00 & 3350.00 & 4 \\
23 & Ft26 & 31 & 620.00 & 39 & 780.00 & 44 & 660.00 & 42 & 1260.00 & 3320.00 & 5 \\
24 & Ft47 & 46 & 920.00 & 40 & 800.00 & 20 & 300.00 & 42 & 1260.00 & 3280.00 & 6 \\
25 & Ft24 & 47 & 940.00 & 38 & 760.00 & 43 & 645.00 & 30 & 900.00 & 3245.00 & 7 \\
26 & Ft25 & 38 & 760.00 & 30 & 600.00 & 29 & 435.00 & 48 & 1440.00 & 3235.00 & 8 \\
27 & Ft0 & 5 & 100.00 & 6 & 120.00 & 16 & 240.00 & 9 & 270.00 & 730.00 & kontrol \\
\hline
\end{tabular}

Keterangan :

Fm48 = E. ovalis Miq. Dandy., Fm33 = C. gigantea R.Br., Fm17 = Piper aduncum L., Fm1 = Lantana camara L., Fm39 = . rugosum Salisb., Fm25 = P. celebicum Miq., Fm7 = Ipomoa quamoclit L., Fm44 = C. prostrate Blume., Fs28 = M.cochinchinensis Lour, Fs2 = Ageratum conyzoides L., Fs25 = P. celebicum Miq., Fs21 = L. capitellata Wedd., Fs33 = C. gigantea R.Br., Fs17 = Piper aduncum L., Fs9 = Hyptis capitata Jacq., Fs20 = C. vulgare Leeench., Ft2 = Ageratum conyzoides L., Ft15 = Physalis angulata L., Ft33 = C. gigantea R.Br., Ft29 = Senna siamea Lam., Ft26 = N. ventricosa Ridsd., Ft47 = Ficus minahassae L., Ft24 = Euphorbia hirta L., Ft25 = P. celebicum Miq.

Hasil seleksi isolat konsorsium mikrob filosfer berdasarkan ranking dengan masingmasing bobot parameter yang diberikan, Tabel 5. Isolat konsorsium mikrob filosfer yang terpilih berdasarkan hasil seleksi

\begin{tabular}{clll}
\hline No & \multicolumn{1}{c}{ Kode isolat } & \multicolumn{1}{c}{ Tumbuhan sumber konsorsium } & Keterangan \\
\hline 1 & Fm38 & Stachytarphyta jamaesensis $($ L.) Vahl. & Daun muda \\
2 & Fm48 & Emmerrilia ovalis Miq Dandy & Daun muda \\
3 & Fs2 & Ageratum cnyzoides L. & Daun sedang \\
4 & Fs25 & Pterospermum celebicum Miq & Daun sedang \\
5 & Fs28 & Memordica sp. & Daun sedang \\
6 & Ft2 & Ageratum cnyzoides L. & Daun tua \\
7 & Ft15 & Physalis angulata L. & Daun tua \\
8 & Ft33 & Calotropis gigantean (Willd) Dryand & Daun tua \\
\hline
\end{tabular}

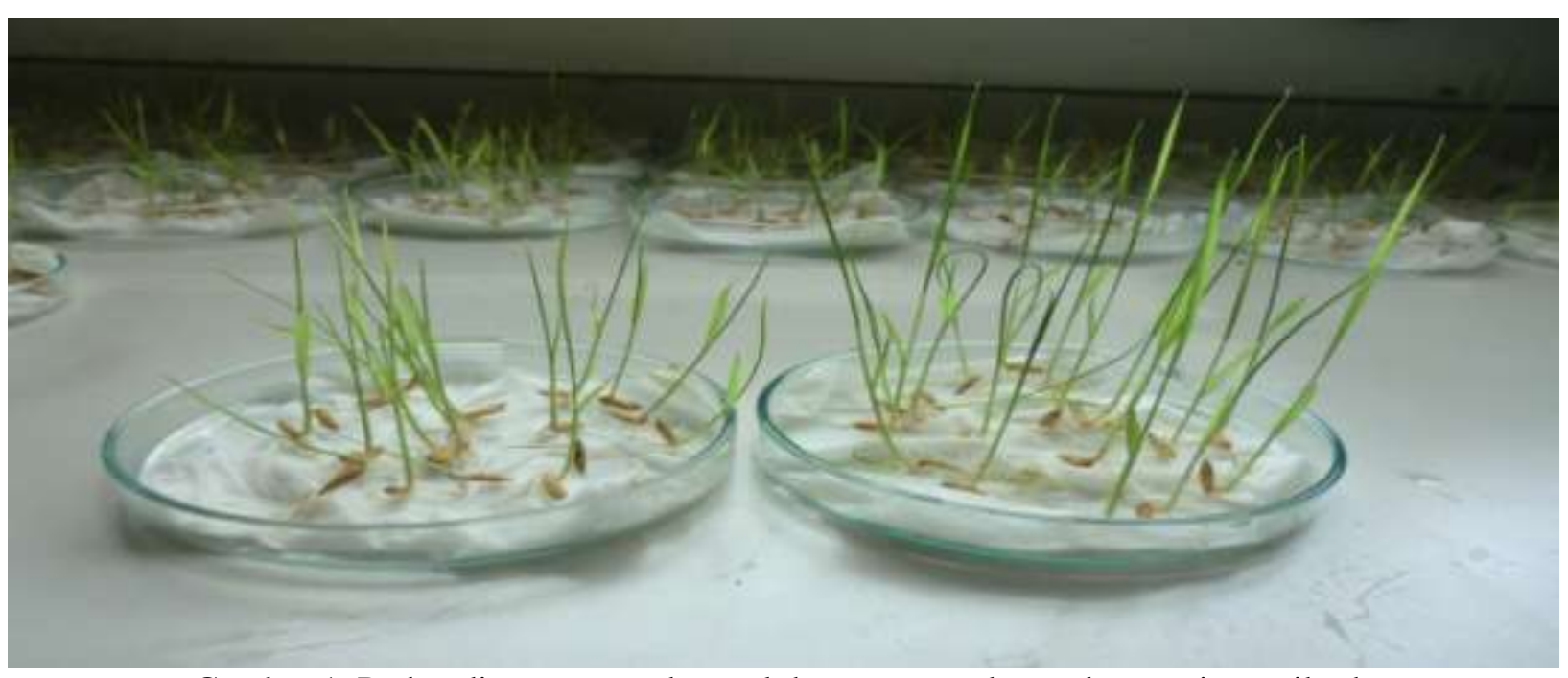

Gambar 1. Perbandingan antara kontrol dengan perendaman konsorsium mikrob

\section{Rizosfer}

Sidik ragam menunjukkan bahwa perlakuan perendaman benih padi pada konsorsium mikrob rizosfer berpengaruh nyata terhadap perkecambahan benih padi. Hasil uji lanjut DMRT pada taraf a $5 \%$ masing-masing parameter panjang akar, panjang daun, bobot diperoleh delapan isolat konsorsium mikrob yang terbaik disajikan pada tabel 5. 
Tabel 6. Rata-rata panjang akar $(\mathrm{cm})$, panjang daun $(\mathrm{cm})$, bobot segar $(\mathrm{g})$ dan bobot kering $(\mathrm{g})$ kecambah benih padi terhadap perlakuan perendaman konsorsium mikrob rizosfer $(\mathrm{R})$

\begin{tabular}{|c|c|c|c|c|c|c|c|c|c|}
\hline No. & Kode Isolat & $\begin{array}{l}\text { Panjang } \\
\text { akar }\end{array}$ & Skor & $\begin{array}{l}\text { Panjang } \\
\text { daun }\end{array}$ & Skor & $\begin{array}{l}\text { Bobot } \\
\text { segar }\end{array}$ & Skor & $\begin{array}{l}\text { Bobot } \\
\text { kering }\end{array}$ & Skor \\
\hline 1 & R0 = Kontrol & 7.640 & 32 & 4.5067 & 14 & 0.0670 & 25 & 0.0229 & 22 \\
\hline 2 & $\mathrm{R} 1$ = Lantana camara $\mathrm{L}$. & 6.520 & 6 & 4.7067 & 23 & 0.0490 & 2 & 0.0218 & 3 \\
\hline 3 & $\mathrm{R} 2=$ Ageratum conyzoides $\mathrm{L}$. & 6.647 & 10 & 4.2933 & 11 & 0.0542 & 8 & 0.0225 & 11 \\
\hline 4 & $\mathrm{R} 3=$ Jussiaea suffruticsa $\mathrm{L}$. & 7.407 & 23 & 4.2600 & 8 & 0.0619 & 13 & 0.0234 & 34 \\
\hline 5 & $\mathrm{R} 4=$ Bidens pilos $a \mathrm{~L}$ & 6.120 & 3 & 3.6333 & 2 & 0.0458 & 1 & 0.0225 & 11 \\
\hline 6 & $\mathrm{R} 5=$ E. prunifolia $\mathrm{Jacq}$ & 7.680 & 33 & 4.7267 & 25 & 0.0669 & 23 & 0.0213 & 2 \\
\hline 7 & $\mathrm{R} 6=O$. sompositus Beauv & 8.107 & 40 & 4.2767 & 9 & 0.0557 & 9 & 0.0229 & 22 \\
\hline 8 & $\mathrm{R} 7$ = Ipomoa quamoclit L. & 8.913 & 47 & 4.7733 & 27 & 0.0823 & 45 & 0.0232 & 28 \\
\hline 9 & $\mathrm{R} 8=D$. agrotistachya Steud. & 8.320 & 43 & 4.1667 & 5 & 0.0860 & 47 & 0.0227 & 16 \\
\hline 10 & $\mathrm{R} 9=$ Hyptis capitata Jacq. & 8.013 & 39 & 4.2900 & 10 & 0.0764 & 39 & 0.0226 & 13 \\
\hline 11 & $\mathrm{R} 10=$ S. pictus Hassk. & 6.520 & 6 & 5.3867 & 43 & 0.0653 & 21 & 0.0227 & 16 \\
\hline 12 & R11 = L. leucocephala Lam. & 7.090 & 15 & 4.5167 & 16 & 0.0708 & 31 & 0.0218 & 3 \\
\hline 13 & $\mathrm{R} 12$ = Ruellia tuberosa L. & 7.167 & 16 & 5.0000 & 36 & 0.0523 & 6 & 0.0232 & 28 \\
\hline 14 & $\mathrm{R} 13=$ =. mutica Forsk. & 7.480 & 26 & 4.8200 & 32 & 0.0803 & 43 & 0.0224 & 9 \\
\hline 15 & $\mathrm{R} 14=S$. sarasinorum & 7.480 & 26 & 4.2133 & 7 & 0.0625 & 15 & 0.0236 & 41 \\
\hline 16 & $\mathrm{R} 15=$ Physalis angulata $\mathrm{L}$. & 7.967 & 38 & 5.1000 & 37 & 0.0740 & 38 & 0.0238 & 43 \\
\hline 17 & $\mathrm{R} 16=$ E. crus-galli $\mathrm{L}$. & 7.407 & 23 & 4.5867 & 18 & 0.0520 & 4 & 0.0234 & 34 \\
\hline 18 & R17 = Piper aduncum L. & 7.013 & 14 & 3.7767 & 3 & 0.0608 & 12 & 0.0228 & 21 \\
\hline 19 & $\mathrm{R} 18=$ Curculigo latifolia $\mathrm{L}$. & 7.313 & 19 & 4.7267 & 25 & 0.0651 & 20 & 0.0230 & 25 \\
\hline 20 & $\mathrm{R} 19=V$. rubescens Blume. & 7.870 & 36 & 4.8067 & 30 & 0.0786 & 42 & 0.0222 & 7 \\
\hline 21 & $\mathrm{R} 20=C$. vulgare Leeench. & 5.734 & 1 & 3.5267 & 28 & 0.0516 & 3 & 0.0220 & 5 \\
\hline 22 & $\mathrm{R} 21=$ L. capitellata Wedd. & 7.847 & 35 & 4.5200 & 17 & 0.0710 & 33 & 0.0231 & 27 \\
\hline 23 & $\mathrm{R} 22=G$. linearis Burm.f. & 8.820 & 46 & 4.5000 & 13 & 0.0678 & 28 & 0.0243 & 46 \\
\hline 24 & $\mathrm{R} 23=$ Mimosa invisa Mart. & 7.527 & 29 & 3.9400 & 4 & 0.0669 & 24 & 0.0227 & 16 \\
\hline 25 & R24 = Euphorbia hirta L. & 7.303 & 18 & 4.5900 & 20 & 0.0638 & 18 & 0.0232 & 28 \\
\hline 26 & $\mathrm{R} 25=P$. celebicum Miq. & 7.173 & 17 & 4.7867 & 29 & 0.0584 & 10 & 0.0233 & 33 \\
\hline 27 & $\mathrm{R} 26=N$. ventricosa Ridsd. & 7.407 & 23 & 4.5867 & 18 & 0.0878 & 48 & 0.0227 & 16 \\
\hline 28 & $\mathrm{R} 27=$ C. mucunoides Desv. & 6.987 & 13 & 4.7800 & 28 & 0.0776 & 41 & 0.0235 & 38 \\
\hline 29 & $\mathrm{R} 28=$ M.cochinchinensis Lour & 6.633 & 8 & 6.5933 & 49 & 0.0637 & 16 & 0.0237 & 42 \\
\hline 30 & R29 = Senna siamea Lam. & 6.967 & 12 & 4.5133 & 15 & 0.0592 & 11 & 0.0207 & 1 \\
\hline 31 & $\mathrm{R} 30=$ M. multiglandulosus & 9.013 & 48 & 4.1867 & 6 & 0.0665 & 22 & 0.0247 & 48 \\
\hline 32 & $\mathrm{R} 31$ = Sida rhombifolia $\mathrm{L}$ & 5.827 & 2 & 4.6067 & 21 & 0.0639 & 19 & 0.0222 & 7 \\
\hline 33 & $\mathrm{R} 32=J$. gossypifolia $\mathrm{L}$. & 7.747 & 34 & 4.7067 & 23 & 0.0909 & 49 & 0.0226 & 13 \\
\hline 34 & $\mathrm{R} 33=C$. gigantea $\mathrm{R} . \mathrm{Br}$. & 8.713 & 44 & 5.6933 & 46 & 0.0705 & 30 & 0.0229 & 22 \\
\hline 35 & $\mathrm{R} 34=$ B. microphylla Kurz & 7.547 & 30 & 5.3767 & 42 & 0.0825 & 46 & 0.0234 & 34 \\
\hline 36 & $\mathrm{R} 35=$ Eleusina indica Gaerth. & 7.347 & 20 & 4.9333 & 35 & 0.0704 & 25 & 0.0224 & 9 \\
\hline 37 & $\mathrm{R} 36=$ C. anagyroides H.B.K. & 7.920 & 37 & 4.8933 & 34 & 0.0771 & 40 & 0.0250 & 49 \\
\hline 38 & $\mathrm{R} 37=$ S. brachycladum L. & 7.497 & 28 & 4.8367 & 33 & 0.0819 & 44 & 0.0226 & 13 \\
\hline 39 & $\mathrm{R} 38=S$. jamaicensis L. & 10.260 & 49 & 5.7533 & 47 & 0.0732 & 37 & 0.0235 & 38 \\
\hline 40 & R39 = I. rugosum Salisb. & 6.637 & 9 & 5.3667 & 41 & 0.0673 & 26 & 0.0235 & 38 \\
\hline 41 & $\mathrm{R} 40=$ C. tenuispica Steud & 7.373 & 22 & 4.8067 & 30 & 0.0721 & 36 & 0.0241 & 44 \\
\hline 42 & $\mathrm{R} 41$ = Cuphea balsam L. & 6.800 & 11 & 5.8267 & 48 & 0.0538 & 7 & 0.0234 & 34 \\
\hline 43 & $\mathrm{R} 42=$ Scoparia dulcis $\mathrm{L}$. & 6.303 & 5 & 4.4700 & 12 & 0.0520 & 5 & 0.0221 & 6 \\
\hline 44 & $\mathrm{R} 43=$ E. odoratum L. & 8.180 & 41 & 5.1733 & 38 & 0.0678 & 27 & 0.0241 & 44 \\
\hline 45 & $\mathrm{R} 44=C$. prostrate Blume. & 8.300 & 42 & 5.2133 & 40 & 0.0716 & 35 & 0.0232 & 28 \\
\hline 46 & $\mathrm{R} 45=$ E. subumbrans Merr. & 8.800 & 45 & 5.6733 & 45 & 0.0711 & 34 & 0.0244 & 47 \\
\hline 47 & $\mathrm{R} 46=$ C.crepidioides $\mathrm{L}$. & 6.173 & 4 & 5.1933 & 39 & 0.0637 & 17 & 0.0232 & 28 \\
\hline 48 & R47 = Ficus minahassae L. & 7.347 & 20 & 5.5533 & 44 & 0.0709 & 32 & 0.0230 & 25 \\
\hline \multirow[t]{2}{*}{49} & $\mathrm{R} 48=$ E. ovalis Miq. Dandy. & 7.557 & 31 & 4.6867 & 22 & 0.0621 & 14 & 0.0227 & 16 \\
\hline & & $\mathrm{n}$ & & $\mathrm{n}$ & & $\mathrm{n}$ & & $\mathrm{n}$ & \\
\hline
\end{tabular}

Keterangan : $\mathrm{n}=$ berpengaruh nyata

Rekapitulasi ranking isolat konsorsium mikrob rizosfer terpilih berdasarkan skoring $\mathrm{x}$ bobot disajikan pada Tabel 7. 
Tabel 7. Rekapitulasi ranking isolat konsorsium mikrob rizosfer terpilih berdasarkan skoring $\mathrm{x}$ bobot

\begin{tabular}{|c|c|c|c|c|c|c|c|c|c|c|c|}
\hline \multirow[t]{2}{*}{ No. } & \multirow{2}{*}{$\begin{array}{l}\text { Kode } \\
\text { Isolat }\end{array}$} & \multicolumn{2}{|c|}{$\begin{array}{l}\text { Panjang akar } \\
\text { bobot } 20(\mathrm{~b})\end{array}$} & \multicolumn{2}{|c|}{$\begin{array}{c}\text { Panjang daun } \\
\text { bobot } 20(\mathrm{~b})\end{array}$} & \multicolumn{2}{|c|}{$\begin{array}{c}\text { Bobot segar } \\
\text { (bobot 15) }\end{array}$} & \multicolumn{2}{|c|}{$\begin{array}{c}\text { Boot kering } \\
\text { (bobot 30) }\end{array}$} & \multirow[t]{2}{*}{ Total } & \multirow[t]{2}{*}{ Ranking } \\
\hline & & $\begin{array}{l}\text { Skor } \\
\text { (s) }\end{array}$ & $\begin{array}{l}\text { Hasil } \\
(\mathrm{s} x \mathrm{x})\end{array}$ & $\begin{array}{l}\text { Skor } \\
\text { (s) }\end{array}$ & $\begin{array}{l}\text { Hasil } \\
(\mathrm{s} x \mathrm{x})\end{array}$ & $\begin{array}{l}\text { Skor } \\
\text { (s) }\end{array}$ & $\begin{array}{l}\text { Hasil } \\
(\mathrm{s} x \mathrm{x})\end{array}$ & $\begin{array}{l}\text { Skor } \\
\text { (s) }\end{array}$ & $\begin{array}{l}\text { Hasil } \\
(\mathrm{s} \times \mathrm{b})\end{array}$ & & \\
\hline 1 & $\mathrm{R} 45$ & 45 & 900.00 & 45 & 900.00 & 34 & 510.00 & 47 & 1410.00 & 3720.00 & 1 \\
\hline 2 & R38 & 49 & 980.00 & 47 & 940.00 & 37 & 555.00 & 38 & 1140.00 & 3615.00 & 2 \\
\hline 3 & R36 & 37 & 740.00 & 34 & 680.00 & 40 & 600.00 & 49 & 1470.00 & 3490.00 & 3 \\
\hline 4 & $\mathrm{R} 15$ & 38 & 760.00 & 37 & 740.00 & 38 & 570.00 & 43 & 1290.00 & 3360.00 & 4 \\
\hline 5 & $\mathrm{R} 43$ & 41 & 820.00 & 38 & 760.00 & 27 & 405.00 & 44 & 1320.00 & 3305.00 & 5 \\
\hline 6 & R34 & 30 & 600.00 & 42 & 840.00 & 46 & 690.00 & 34 & 1020.00 & 3150.00 & 6 \\
\hline 7 & R44 & 42 & 840.00 & 40 & 800.00 & 35 & 525.00 & 28 & 840.00 & 3005.00 & 7 \\
\hline 8 & $\mathrm{R} 7$ & 47 & 940.00 & 27 & 540.00 & 45 & 675.00 & 28 & 840.00 & 2995.00 & 8 \\
\hline 9 & R0 & 32 & 640.00 & 14 & 280.00 & 25 & 375.00 & 22 & 660.00 & 1955.00 & kontrol \\
\hline
\end{tabular}

Keterangan :

$\mathrm{R} 45=$ E. subumbrans Merr., R38 = S. jamaicensis L., R36 = C. anagyroides H.B.K., R15 = Physalis angulata L., R43 = E. odoratum L., R34 = B. microphylla Kurz, R44 = C. prostrate Blume., R7 = Ipomoa quamoclit L.

Hasil seleksi isolat konsorsium mikrob filosfer berdasarkan ranking dengan masingmasing bobot parameter yang diberikan, diperoleh delapan isolat konsorsium mikrob rizosfer yang terbaik disajikan pada Tabel 8 .

Tabel 8. Isolat konsorsium mikrob rizosfer yang terpilih berdasarkan hasil seleksi

\begin{tabular}{lll}
\hline No & \multicolumn{1}{c}{ Kode isolat } & \multicolumn{1}{c}{ Tumbuhan sumber konsorsium } \\
\hline 1 & R7 & Ipomoea quamoclit L. \\
2 & R15 & Physalis angulata L. \\
3 & R34 & Breynia microphylla (Kurz ex T \& B) M.A. \\
4 & R36 & Crotalaria anagyroides H. B. Ks. \\
5 & R38 & Stachytarphyta jamaesensis (L.) Vahl. \\
6 & R43 & Eupatorium odoratum L. \\
7 & R44 & Cyathula prostata (L) Blume \\
8 & R45 & Erythrina subumbranss (Hassk) Merr. \\
\hline
\end{tabular}

\section{Pembahasan}

Seleksi konsorsium menunjukkan bahwa, perlakuan konsorsium mikrob dengan metode perendaman benih padi, berpengaruh nyata terhadap panjang akar, panjang tunas, bobot segar dan bobot kering semai, meskipun tidak selalu lebih baik dibanding kontrol. Sebaliknya terdapat konsorsium mikrob yang menghambat pertumbuhan kecambah. Hal ini menunjukan bahwa konsorsium mikrob menunjukkan tiga macam pengaruh, yaitu berpengaruh positif, netral dan negatif.

Merujuk hasil penelitian Gofar (2003), mengelompokkan tiga pengaruh konsorsium, yaitu kelompok menguntngkan bila konsorsium mikrob mampu meningkatkan pertumbuhan tanaman, kelompok netral ditunjukkan bila pengaruh konsorsium mikrob tidak nyata dan kelompok merugikan, bila terjadi adanya pertumbuhan yang tidak lebih baik dibanding dengan kontrol.

Fase perkecambahan yang meliputi pertumbuhan dan perkembagan akar pertama (radikula) dan daun pertama (plumula). Secara fisiologis perkecambahan diregulasi oleh cadangan makanan dan fitohormon yang terdapat dalam biji. Pertumbuhan akar yang normal menjamin perkembangan tajuk. Aplikasi mikrob dengan metode seed treatment (seed dressing) melakukan penetrasi lebih awal pada embrio biji padi dan berkembang pada akar ketika akar mulai tumbuh. Wedhastri (2002) melaporkan bahwa, kehadiran mikrob dapat merangsang prosesproses enzimatik, yang secara biologis meningkatkan perkecambahan benih dan mempercepat sintesis senyawa-senyawa nitrogen organik pada akar.

Pengaruh positif yang ditimbulkan oleh perlakuan konsorsium mikrob, diduga adanya kemampuan konsorsium mikrob mensekresikan senyawa perangsang tumbuh terhadap kecambah benih padi. Sejalan dengan pendapat Fahey et al. (1991), bahwa aplikasi mikrob pada benih tanaman padi, mikrob dapat masuk ke dalam jaringan benih padi dan akan tumbuhan di dalam jaringan benih, mikrob tersebut dapat mengkolonisasi dan bertahan serta berkembang di dalam benih. 


\section{Jurnal Ogrotech 8 (2) 62-72}

Fitohormon yang terkandung di dalam mikrob penyusun konsorsium merangsang pembentukan akar, sehingga serapan hara lebih efektif. Secara alami, akar berperan sebagai saluran untuk mensuplai unsur hara dan air dari tanah ke tanaman dan lokasi sintesis serta pertukaran sejumlah hormon dalam tanaman. Pertumbuhan akar yang normal menjamin perkembangan tajuk yang normal

Kehadiran mikrob menguntungkan bagi tanaman inang, karena meningkatkan pertumbuhan tanaman (Sturz \& Nowak 2000), menghasilkan fitohormon (Taller \& Wong 1989; Leveau 2001; Morris 2001). dapat menambat $\mathrm{N}_{2}$ (Hirano \& Upper 2000; Kennedy et al. 1997) dan meningkatkan resistensi tanaman pada kondisi tertekan terhadap lingkungan (Azevado et al. 2000). Peran mikrob tersebut diduga berperan dalam memacu perkecambahan benih padi. Didukung oleh Pendapat Salisbury \& Ross (1992), hormon selain diproduksi oleh tanaman, hormon juga disekresikan oleh mikrob yang hidup di sekitar tanaman.

Mikrob menghasilkan macam-macam substansi yang secara langsung atau tidak langsung mempengaruhi pertumbuhan tanaman (Rao 2007). Mikrob yang hidup dalam tanah memegang peranan dalam meningkatkan pertumbuhan tanaman, sehubungan dengan perombakan bahan organik, sekeresi hormon dan fiksasi $\mathrm{N}_{2}$ (Sutedjo $d k k$. 1996), Dijumpai ketergantungan tanaman dengan aktivitas mikrob, seperti tanaman pepolongan yang berasosiasi dengan bakteri pembentuk bintil akar, bakteri mengkonversi nitrogen atmosfer $\mathrm{N}_{2}$ menjadi senyawa nitrogen $\mathrm{NH}_{3}$ yang dapat digunakan tanaman utnuk tumbuh, memegang peranan penting daur ulang nutrien (Sunatmo 2009) dan mikrob yang hidup di filosfer tanaman padi nyata mensekresikan fitohormon (Padua et al. 2001).

\section{Kesimpulan}

Berdasarkan hasil percobaan dapat disimpulkan :

1. Isolat konsorsium mikrob filosfer dan rizosfer nyata memberikan pengaruh positif, netral dan negatif terhadap perkecambahan benih padi

2. Delapan isolat konsorsium mikrob filosfer yang terbaik, yaitu : Fm38 (Stachytarphyta jamaesensis (L.) Vahl.), Fm48 (Emmerrilia ovalis Miq Dandy), Fs2 (geratum cnyzoides L.), Fs25 (Pterospermum celebicum Miq), Fs28 (Memordica sp.), Ft2 (Ageratum cnyzoides L.), Ft15 (Physalis angulata L.) dan Ft33 (Calotropis gigantean (Willd) Dryand).
e-ISSN : 2621-7236

p-ISSN : 1858-134X

3. Delapan isolat konsorsium mikrob rizosfer yang terbaik, yaitu : R7 (Ipomoea quamoclit L.), R15 (Physalis angulata L.), R34 \{Breynia microphylla (Kurz ex T \& B) M.A.\}, R36 (Crotalaria anagyroides H. B. Ks.), R38 \{Stachytarphyta jamaesensis (L.) Vahl.\}, R43 (Eupatorium odoratum L.), R44 \{Cyathula prostata (L.) Blume $\}$ dan R45 \{Erythrina subumbranss (Hassk) Merr.\}

\section{Daftar Pustaka}

Anas I. 1989. Biologi Tanah dalam Praktek. Bogor, Institut Pertanian Bogor. 161h.

Azevado JL., Maccheroni WJr. Pereira JO. 2000. Endophytic microorganism : A review on insect control and recent advances on tropical plants. Electronic J. of Biotech 3(1):1 - 4. Available at : http://www.ejb.org/content/vol3/issue/full/ 4.

Bills GF. 1996. Isolation and analysis of endophytic fungal communities from woody plants. P. $31-65$. Redlin S, Carries LM (Ed). Sistematic, ecology, and evolution of endophytic fungi in grasses and woody plants. APS Press, St Paul, MN. (in press).

Darmawan J, JS. Baharsjah. 2010. Dasar-Dasar Fisiologi Tanaman. Jakarta (IN) : SITC.

Fahey JW, MB Dimock, SF Tomasino. 1991. Genetically engineered endophytes as biocontrol agents : as case study from industry. In microbial Ecology of leaves. New York (US) : Springer - Verlag.

Gofar N. 2003. Eksplorasi konsorsium Mikrob daun asal tumbuhan dari ekosistem air hitam Kalimantan Tengah dan aplikasinya sebagai pemacu pertumbuhan tanaman jagung pada ultisol [Disertasi]. Bandung: Program Pascasarjana Universitas Padjadjaran.

Hirano SS, Upper CD. 2000. Bacteria in the leaf ecosystem with emphasis on Pseudomonas syringae-a pathogen, ice nucleus, and epiphyte. Microbiol and Mol.Biol. review. 64 (3):624-653. Available at : http://mmbr.asm.org/cgi/content/full/64/3/ 624.

Hindersah R, Tualar S. 2004. Potensi rizobakteri Azotobacter dalam meningkatkan 
Jurnal agrotech 8 (2) 62-72

kesehatan tanah. Jurnal Natur Indonesia 5(2):127-133.

Kennedy IR, Pereg-Gerk LL, Wood C, Dealer R, Gilchrist K, Katuplitiya S. 1997. Biological nitrogen fixation in nonleguminous field crops: facilitating the evolution of an effective association between Azospirillum and wheat. Plant and Soil 194:65-79.

Leveau J. 2001. Nutrient ecology of bacterial colonizers of the phyllosphere. University of California, Berkeley. Available at : http://www.cnr.berkeley.edu/icelab/people/ johannew.html-33k.

Matjik AA, Sumertajaya IM. 2006. Perancangan Percobaan dengan Aplikasi SAS dan MINITAB. IPB Press, Bogor.

Morris C. 2001. Impact of biofilms on the ecology and control of epiphytic bacteria. Interdisciplinary Plant Biology Seminar Spiker, January 29, 2001. Plant pathology Station, INRA, France.

Padua VLM, Masuda HP, Alves HM, Schwarcz KD, Baldani VLD, Ferreira PCG, Hemerly AS. 2001. Effect of endophytic bacterial indole-acetic acid (IAA) on rice development. Rio de Janeiro: Dept. Bioquimica medica.

Rao NSS. 2007. Mikroorganisme Tanah dan Pertumbuhan Tanaman. Susilo, penerjemah. Jakarta: UI Pr.. Terjemahan dari Soil Microorganism and Plant Growth. Oxford and IBM publishing CO.
e-ISSN : 2621-7236

p-ISSN : 1858-134X

Rustam 2011. Potensi Bakteri penghasil metabolit sekunder untuk pengendalian penyakit hawar pelepah padi yang disebabkan oleh Rhizoctonia solani Kuhn [Disertasi]. Bogor: Sekolah Pascasarjana Institut Pertanian Bogor.

Salisbury FB, Ross CW. 1992. Fisiologi Tumbuhan. Penerjemah : Lukman DR, Sumaryono. Bandung : ITB. Terjemahan Plant Physiology.

Sturz AV., Nowak J. 2000. Endophytic communities of rhizobacteria and strategis required to create yield-enhancing association with crops. Appl. Soil Ecol. 15 : $183-190$.

Sunatmo TI. 2009. Mikrobilogi Esensial. Jakarta (ID): Ardy Agency

Sutedjo MM, AG. Kartasapoetra, RD.S. Sastroatmodjo. 1996. Mikrobiologi Tanah. Jakarta (ID): Rineka Cipta.

Taiz L., Zeiger E. 1991. Plant Physiology. California: The Benyamin/Cumming.

Taller BJ, Wong TY. 1989. Cytokinins in Azotobacter vinelandii in culture medium. Appl. Environ. Microbial 55:266-267.

Vaish SS, Ahmed SB, Prakash K. 2011. First Documentation on status of barley disease from the high altitude cold arid TransHimalaya Ladakh region of India. Crop Prot 30: 1129 - 1137. 